\title{
Demand and Unmet Need for Means of Family Limitation in Rwanda
}

\section{By Dieudonné Muhoza Ndaruhuye, Annelet Broekhuis and Pieter Hooimeijer}

Dieudonné Muhoza Ndaruhuye is lecturer, Department of Applied Statistics, National University of Rwanda, Butare, Rwanda. Annelet Broekhuis is senior lecturer, Department of International Development Studies, and Pieter Hooimeijer is professor, Department of Human Geography and Regional

Planning, both at

Utrecht University, Utrecht, The Netherlands.

CONTEXT: Rwanda is the most densely populated country in Africa, with substantial annual population growth. The
current government seeks new policies for family limitation as a way to facilitate more sustainable development.

METHODS: Data from the 2005 Rwanda Demographic and Health Survey were used for a two-step analysis; binary logistic regression was used to identify factors associated with desiring to stop childbearing and having unmet need.

RESULTS: Eighty-seven percent of women aged 15-49 approve of family planning, but only 64\% believe that their partner approves of it. There is a high level of unmet need for family limitation; $58 \%$ of women who want to stop childbearing do not use modern contraceptives. Demand was lower among women who did not approve of family planning, those who did not know their partner's attitude toward family planning and those who had discussed family planning with their partner fewer than three times. Unmet need was higher among women who did not approve of family planning, those who believed their partner did not approve of family planning or who did not know his attitude, and those who had never discussed family planning with their partner or had done so only once or twice.

CONCLUSIONS: Negative attitudes toward family planning and failing structures of provision are the dominant constraints on the use of modern contraceptives in Rwanda. Community-based family planning services could greatly expand access, especially in underserved provinces.

International Perspectives on Sexual and Reproductive Health, 2009, 35(3):122-130

Rwanda faces serious development problems. A high population growth rate-2.5\% a year in the period 2000$2005-$ is one of them. The vast majority of the country's nine million inhabitants live in rural areas, and 90\% of the population work in agriculture. The country has the highest population density in Africa (350 persons per square $\mathrm{km}$ ) and, with a gross domestic product of US $\$ 250$ per capita in 2005, it belongs to the group of very low-income countries. ${ }^{1}$ The country's high population growth contributes to continuing pressure on natural resources, particularly land, which is thought to be one of the underlying causes of the ethnic tensions that contributed to the killing of 800,000 Rwandans in $1994 .^{2}$ The country achieved an impressive economic growth rate $(6 \%)$ in 2000-2006; however, during the same period, the number of poor people increased by half a million. ${ }^{1}$

Population issues have been on the government's agenda since 1981, when the National Office of Population (ONAPO) was created. Between 1981 and 1990, ONAPO focused on improving access to family planning services and promoting family planning through trained communicators known as abakangurambaga ("awakeners of the people"). ${ }^{3}$ In 1990, ONAPO's activities were intensified when it began to provide modern contraceptives throughout the country; at this time, family planning became part of a broader national development policy that was aimed at increasing agricultural production, improving public health, and promoting the education, employment and empowerment of women. Development efforts in these fields were expected to create an environment favorable to behavioral changes that would result in lower fertility; ${ }^{4}$ the aim was to reduce the total fertility rate from 8.6 to 4.0 and to raise the contraceptive prevalence rate from $2 \%$ to $48 \%$ by $2000 .{ }^{5}$ Implementation of the various policies facilitated a significant increase in the use of contraceptives: In 1983 , only $11 \%$ of the population used contraceptives, while in 1992 the figure was 21\% (Table 1). ${ }^{6-9}$

After the genocide in 1994, the population policy shifted toward reuniting dislocated families, and although ONAPO remained in existence, no activities related to slowing population growth were undertaken. Eight years later, ONAPO was dissolved and all population matters were transferred to the Ministry of Health. In 2003, the government formulated a new national population policy plan aimed at curbing demographic growth, managing natural resources, ensuring food security, providing all children with access to primary and secondary education, realizing equal opportunity, and engaging both men and women in development. ${ }^{4}$ Family planning was not mentioned in this plan; the assumption was that improved education and higher levels of wealth would stimulate the demand for and use of means for family limitation.

In February 2007, the government of Rwanda announced that it was considering new legislation to limit the size of Rwandan families: It proposed that three children per woman should become the standard. ${ }^{10}$ However, 
forced family planning is a sensitive issue in Rwanda, given cultural attitudes and the losses experienced during the genocide. The plan was never presented to parliament and the president later characterized it as a family planning "sensitization" campaign. ${ }^{11}$ This is indicative of the current administration's ambivalence toward family planning.

Although the government acknowledged in the 2007 Human Development Report that high population growth hampers the country's economic growth and contributes to environmental degradation, policy has been focused on sustainable economic and human development as means to limit population growth, rather than on a comprehensive family planning program. Community mobilization and gender empowerment have been seen as important factors in reducing the total fertility rate. ${ }^{1,12}$ However, provision of reproductive health care could be more effective in slowing population growth because unmet need for family limitation is high. This article explores some aspects of that potential.

\section{Fertility Decline and Structures of Provision}

In Rwanda, the onset of the fertility decline was disturbed by civil war (Table 1). Although data for the period immediately following the genocide in 1994 are lacking, the Demographic and Health Survey data show that the ideal number of children rose from 4.4 in 1992 to 5.0 in 2000 and that the demand for family limitation decreased from $30 \%$ to $18 \%$ (a figure even lower than that for 1983) during that period. By 2005, the ideal number of children had returned to the level of the early 1990s. The demand for family planning services to limit family size had also increased, but not to the level of 1992. What had improved was the degree to which this demand was being met. The percentage of women considered to have an unmet need for family limiting dropped from 89\% in 1983 to 58\% in 2005. * However, Rwanda still lags behind other countries. If unmet need for means of spacing and limiting births are both taken into account, Rwanda has one of the highest levels of unmet need in the world-35\% of fecund women in a union want to avoid or postpone their next child but are not using contraceptives (not shown). ${ }^{13}$

As a result of the conflict of the early 1990s, Rwanda has reverted to the early phase of the demographic transition. Previous research shows that in this phase, socioeconomic variables such as wealth and education are not related to demand for family planning, although they are related to the ability to obtain proper family planning services. ${ }^{14}$ Instead, sociocultural values-such as attitudes toward the use of contraceptives and the gender power balance in households-are hypothesized to have a strong effect on both the demand for and the actual practice of contraception.

Religion in Rwanda plays a double role in regard to fertility. The first role is in shaping the attitudes of the population. Most Rwandans claim a religious affiliation-in 2002, 50\% of the population was Catholic, 27\% Protestant and 13\% Adventist. ${ }^{15}$ The second role is in the provision of social services (particularly education and health
TABLE 1. Trends in fertility and demand for contraception among all fecund women in Rwanda, 1983, 1992, 2000 and 2005

\begin{tabular}{lcrrr} 
Indicator & 1983 & 1992 & 2000 & 2005 \\
\hline Total fertility rate & 8.5 & 6.2 & 5.8 & 6.1 \\
Ideal no. of children & 6.3 & 4.4 & 5.0 & 4.5 \\
Demand for family planning (\%) & na & 61.6 & 48.8 & 55.3 \\
Desire for family limitation (\%) & 18.6 & 30.4 & 17.5 & 23.3 \\
Unmet need as a \% of the & & & & \\
$\quad$ desire for family limitation & 88.7 & 74.7 & 66.3 & 57.5 \\
Total practicing contraception (\%) & 11.2 & 21.2 & 10.5 & 17.3 \\
\% of users limiting births & 25.1 & 51.9 & 44.7 & 56.9
\end{tabular}

Note: na=not available. Sources: 1983—reference 6. 1992—reference 7. 2000 - National Institute of Statistics, Rwanda Demographic and Health Survey 2000, Calverton, MD, USA: ORC Macro, 2001.2005-reference 4.

care), which has been dominated by religious institutions since colonial times. Of the 406 public health facilities-37 hospitals and 369 health centers (including dispensaries)-in 2003, 40\% had a religious affiliation. Because $60 \%$ of facilities with religious affiliations ( $25 \%$ of all facilities) do not offer modern methods of contraception, ${ }^{16}$ women living in the areas they serve may have great difficulty obtaining such methods. To fill these gaps in care, starting in 1980, the government began to open secondary posts in which modern methods of family planning could be obtained. By 2003, there were 34 secondary posts. Creating these posts was an important step, because $73 \%$ of women using contraceptive methods receive them from government services. ${ }^{17}$ The private sector is not very well developed in Rwanda, especially in rural areas, and accounts for only $14 \%$ of the women receiving contraceptive services. The other 13\% obtain methods from a variety of other sources. The main private organization involved in family planning is the Association Rwandaise pour le BienÊtre Familial (ARBEF), a nonprofit organization established in 1986 that focuses primarily on family planning and sexual and reproductive health. ARBEF has permanent stations in the cities of Kigali, Butare, Ruhengeri and Gisenyi. In 2004, it provided 8\% of all the contraceptives issued in Rwanda.

To inform Rwanda's population policy debate, we first set out to identify factors associated with the desire to limit family size. Our second step was to determine the individual and contextual constraints associated with nonuse of contraceptives by women who want no more children.

\section{METHODS}

Data for this study were drawn from the 2005 Rwanda Demographic and Health Survey (RDHS). ${ }^{4 \dagger \neq}$ We selected from the larger data set the group of fecund women in the

*Women are considered to have an unmet need for means of family limitation if their last child or current pregnancy was unwanted or if they do not want to have additional children but are not using contraceptives.

†See reference 4 for full details of the sampling methodology employed in data collection.

$\ddagger$ The questionnaire used in Rwanda contains all common variables, with one exception: As a result of the trauma experienced during the genocide in the early 1990 s, ethnicity is no longer recorded on identification papers or in registers, censuses or surveys. 
age-group 15-49 years. A woman is assumed to be fecund unless she declares that she is infecund, has had a hysterectomy or is menopausal. Women are also considered infecund if they are neither pregnant nor experiencing postpartum amenorrhea but have not menstruated for six or more months, or are married, have not practiced contraception during the previous five years, have not given birth and are not currently pregnant. The sample was further limited to the 4,817 women living with partners, whether or not they were married. This is the population most at risk of having an unmet need for some form of family planning.

In our analyses, we draw extensively from the literature on factors associated with the use of family planning. We selected four sets of variables that we expected, given the results of previous research, ${ }^{18}$ to be relevant for explaining the demand or unmet need for family limitation.

The first set concerns the characteristics of a woman that are expected to influence her demand for and practice of birth control, such as age at the time of the survey, educational level, occupation, religion, place of residence (rural or urban) and province of residence. ${ }^{19-23}$

Fertility behavior is also a function of the characteristics of the woman's partner and the socioeconomic status of the household. ${ }^{24-26}$ These factors can strengthen or weaken the impact of variables on individual women. Thus, the second set of variables includes the partner's education level and occupation, agreement with the partner on the desired number of offspring and the level of household wealth.

Because we were interested in the contribution of current family planning program activities to building and meeting the demand for methods of limiting births, the third set includes variables measuring exposure to information about and access to family planning facilities, such as the number of contraceptive methods known and information about family planning received through the media, a family planning worker or a visit to a health facility. ${ }^{27}$

The fourth set of variables was used to measure attitudes toward the use of contraceptives-the woman's attitude, her perception of her partner's attitude and how often they discussed family planning. ${ }^{28,29}$

We first examined descriptive statistics to identify possible links between these variables and the demand and unmet need for means of family limitation. We then used multivariate models to identify the significance and relative weight of each of the variables. The analysis consisted of two parts. In the first, we calculated the proportion of women who wanted to limit family size; in the second, we

\footnotetext{
*We preferred this two-step approach to a multinomial regression because wanting to stop childbearing is different from having an unmet need: To those who do not want to limit births, unmet need is irrelevant. From a statistical point of view, this implies that running a multinomial model would violate the assumption of the independence of irrelevant alternatives. The more substantive reason to divide the analysis into two parts is that policies aimed at influencing desire for smaller families will take a different form than policies aimed at easing restrictions and constraints on contraceptive use.
}

analyzed the level of unmet need among these women. Binary logistic regression was used to estimate the odds of desiring to stop childbearing and the odds of having unmet need.*

\section{RESULTS}

Among all fecund women living with a partner, 27\% wanted to stop having children (Table 2). Thus, 1,321 women were considered to have a demand for family limitation; of this group, 57\% were not practicing contraception and therefore were classified as having an unmet need for permanent methods of family planning.

Women's educational level is related to demand, though the relation is U-shaped rather than linear. However, there is a very clear linear relation to unmet need, which ranged from 69\% among those who received fewer than three years of education to $27 \%$ among those who received at least 10 years of schooling. In keeping with findings from earlier studies, women who worked in agriculture had the lowest demand (26\%) and the highest level of unmet need (61\%). Protestants had lower levels of demand and a higher level of unmet need than Catholics or others. The first of our two geographic indicators, which distinguished between urban and rural residence, yielded the expected results. Given that the provision of family planning services is much better in urban areas than in rural areas, the level of unmet need found in urban areas is lower ( $45 \%$ vs. $62 \%$ ). The second geographic indicator, the province of residence, also turned out as expected. Because both Kigali province and East province have a large population of displaced persons, we assumed that, in keeping with the theory of fertility migration, ${ }^{30}$ that population would want to have fewer children than people in other provinces and would act to achieve this aim. The level of unmet need was lower in Kigali province as expected (38\%), but less so for East province (55\%). The variables for household wealth and the education and occupation of the partner, like the individual characteristics of the women, could be expected to show higher levels of demand and lower levels of unmet need in the wealthier subgroups. However, only the richest $20 \%$ of households and the partners with the most education and the highest salaries had levels of unmet need substantially lower than those in other subgroups. Demand was higher and unmet need lower among women who received information about family planning at health facilities than among those who received no information at these facilities or those who did not attend such a facility.

Although the vast majority of women (4,192 out of 4,817 ) approved of family planning, about one in five did not know whether their partner approves and about one in seven reported that he disapproved. In both instances, the levels of unmet need were extremely high. Slightly more than $50 \%$ of the women said they had discussed family planning with their partner only once or twice, or had never brought up the subject. Levels of unmet need were particularly high among these groups. 
TABLE 2. Selected characteristics among fecund women, by desire for family limitation and unmet need, Rwanda Demographic and Health Survey, 2005

\begin{tabular}{|c|c|c|c|c|c|c|c|}
\hline Variable & No. & $\begin{array}{l}\text { Desire family } \\
\text { limitation (\%) }\end{array}$ & $\begin{array}{l}\text { Have unmet } \\
\text { need }(\%) \dagger\end{array}$ & Variable & No. & $\begin{array}{l}\text { Desire family } \\
\text { limitation (\%) }\end{array}$ & $\begin{array}{l}\text { Have unmet } \\
\text { need (\%)† }\end{array}$ \\
\hline \multirow[t]{2}{*}{ ALL } & 4,817 & 27.4 & 57.3 & \multicolumn{4}{|c|}{ Partner's occupation‡ } \\
\hline & & & & Agriculture & 3,519 & 25.0 & 63.9 \\
\hline \multicolumn{4}{|l|}{ Education } & Craftsman & 655 & 33.0 & 48.6 \\
\hline $0-2$ yrs. & 1,836 & 30.1 & 69.4 & Mid-salaried & 322 & 32.3 & 44.2 \\
\hline 3-6yrs. & 1,998 & 23.8 & 56.4 & High-salaried & 221 & 37.1 & 29.3 \\
\hline 7-9yrs. & 656 & 26.5 & 42.5 & Don't know & 100 & 41.0 & 51.2 \\
\hline \multirow[t]{2}{*}{$\geq 10$ yrs. } & 327 & 36.7 & 26.7 & & & & \\
\hline & & & & \multicolumn{4}{|c|}{ Partner's desired no. of children $¥$} \\
\hline \multicolumn{4}{|l|}{ Occupation } & Same & 1,856 & 26.5 & 45.9 \\
\hline Agriculture & 3,402 & 26.2 & 61.4 & Fewer & 939 & 27.5 & 53.9 \\
\hline Not working & 940 & 27.7 & 59.6 & More & 628 & 29.9 & 70.7 \\
\hline Salaried & 475 & 35.8 & 32.4 & Don't know & 1,394 & 27.5 & 67.6 \\
\hline \multicolumn{4}{|l|}{ Religion } & \multicolumn{4}{|c|}{ Visited by family planning worker in previous 12 mos. } \\
\hline Catholic & 2,125 & 30.1 & 53.2 & Yes & 278 & 27.7 & 53.2 \\
\hline Protestant & 2,477 & 24.8 & 62.3 & No & 4,539 & 27.4 & 57.6 \\
\hline \multirow{2}{*}{ Other } & 215 & 31.2 & 50.7 & & & & \\
\hline & & & & \multicolumn{4}{|c|}{ Told about family planning at health facility } \\
\hline Locality & & & & Was told & 865 & 30.9 & 42.7 \\
\hline Urban & 935 & 35.6 & 44.7 & Was not told & 1,370 & 25.5 & 54.7 \\
\hline Rural & 3,882 & 25.5 & 61.5 & Was not at facility & 2,582 & 27.3 & 64.1 \\
\hline \multicolumn{4}{|l|}{ Province } & \multicolumn{4}{|c|}{ Heard about family planning via media } \\
\hline Kigali & 447 & 39.1 & 38.3 & Yes & 2,313 & 29.5 & 46.6 \\
\hline East & 1,100 & 29.7 & 55.4 & No & 2,504 & 25.5 & 68.8 \\
\hline North & 820 & 27.7 & 56.4 & & & & \\
\hline West & 1,290 & 24.9 & 64.8 & \multicolumn{4}{|c|}{ Approves of family planning } \\
\hline \multirow[t]{2}{*}{ South } & 1,160 & 23.4 & 63.8 & Yes & 4,192 & 28.4 & 53.9 \\
\hline & & & & No & 447 & 20.6 & 91.3 \\
\hline \multicolumn{4}{|c|}{ Household wealth index (quintiles) } & No response & 178 & 21.9 & 82.1 \\
\hline Poorest & 947 & 24.7 & 68.4 & & & & \\
\hline Poorer & 937 & 26.3 & 58.5 & \multicolumn{4}{|c|}{ Partner approves of family planning } \\
\hline Middle & 924 & 25.9 & 65.3 & Yes & 3,084 & 29.1 & 43.6 \\
\hline Richer & 1,003 & 24.0 & 63.5 & No & 729 & 26.5 & 86.0 \\
\hline Richest & 1,006 & 35.9 & 39.9 & Don't know & 1,004 & 23.1 & 86.2 \\
\hline \multicolumn{4}{|c|}{ Partner's education $\neq$} & \multicolumn{4}{|c|}{ Discussed family planning with partner } \\
\hline $0-2$ yrs. & 1,665 & 27.4 & 65.2 & $\geq 3$ times & 2,149 & 31.2 & 40.8 \\
\hline 3-6yrs. & 1,931 & 27.6 & 60.4 & Once or twice & 1,300 & 23.6 & 67.1 \\
\hline 7-9yrs. & 619 & 22.8 & 46.8 & Never & 1,267 & 23.1 & 83.6 \\
\hline$\geq 10$ yrs. & 480 & 32.9 & 31.0 & No response & 101 & 49.5 & 64.0 \\
\hline Don't know & 122 & 26.2 & 68.8 & & & & \\
\hline
\end{tabular}

\section{Demand for Family Limitation}

The first model in Table 3 (page 126) includes the individual characteristics of the women and the two geographic factors. The second model adds the characteristics of the household, the third adds exposure to family planning services and the fourth adds attitudes toward family planning.

Women's socioeconomic factors played a negligible role in their demand for means of family limitation (Model 1). There were no significant differences except in terms of the woman's occupation: Salaried women were significantly more likely to have a demand for family limitation than those working in agriculture (odds ratio, 1.4). Contrary to our expectations, religious affiliation did not influence the demand for means of family limitation. In contrast, regional variables were associated with women's desire to limit family size. The odds of desiring to limit family size were significantly lower among women living in South, West or North provinces than among those living in Kigali or East province (0.4-0.6 vs. 0.9-1.0). Also, rural women were less likely than urban woman to have a demand for family limitation (0.7).
When we included the household context variables (Model 2), the overall picture changed somewhat. Province of residence maintained its significance, but rural residence became only marginally significant and women's occupation lost its significance. Among the household context variables, only household wealth and partner's occupation were related to the desire for family limitation. Women from the wealthiest households and women who were married to craftsmen or men with midlevel salaries were more likely than women from poorer households or women married to cultivators to have a desire for family limitation (odds ratio, 1.4-1.6).

Among variables measuring exposure to information about contraception and access to family planning facilities (Model 3), not being informed about family planning at a health facility was negatively associated with the desire to limit family size.

Finally, when the variables on attitudes toward and perceptions of family planning were added (Model 4), the level of significance of almost all factors included in earli- 


\begin{tabular}{|c|c|c|c|c|c|c|c|c|c|}
\hline Variable & Model 1 & Model 2 & Model 3 & Model 4 & Variable & Model & Model 2 & Model 3 & Model 4 \\
\hline \multirow[t]{2}{*}{ Age (mean, 31.3 yrs.) } & $1.19^{* *}$ & $1.20^{* *}$ & $1.20^{* *}$ & $1.20^{* *}$ & \multicolumn{5}{|c|}{ Partner's desired no. of children‡ } \\
\hline & & & & & Same (ref) & na & 1.00 & 1.00 & 1.00 \\
\hline Education & & & & & Fewer & na & 0.93 & 0.93 & 0.95 \\
\hline $0-2$ yrs.(ref) & 1.00 & 1.00 & 1.00 & 1.00 & More & na & 0.88 & 0.88 & 0.97 \\
\hline 3-6yrs. & 1.10 & 1.05 & 1.02 & 1.00 & Don't know & na & 0.92 & 0.98 & 1.16 \\
\hline 7-9yrs. & 1.00 & 0.89 & 0.83 & $0.80 \dagger$ & & & & & \\
\hline \multirow[t]{2}{*}{$\geq 10 \mathrm{yrs}$} & 0.98 & 0.77 & $0.67^{*}$ & $0.66^{*}$ & \multicolumn{5}{|c|}{ Visited by family planning worker in previous 12 mos. } \\
\hline & & & & & Yes (ref) & na & na & 1.00 & 1.00 \\
\hline \multicolumn{5}{|l|}{ Occupation } & No & na & na & 1.06 & 1.06 \\
\hline Agriculture (ref) & 1.00 & 1.00 & 1.00 & 1.00 & & & & & \\
\hline Not working & $1.21 \dagger$ & 1.10 & 1.15 & 1.18 & \multicolumn{5}{|c|}{ Told about family planning at health facility } \\
\hline \multirow[t]{2}{*}{ Salaried } & $1.38^{*}$ & 1.06 & 1.07 & 1.04 & Was told (ref) & na & na & 1.00 & 1.00 \\
\hline & & & & & Was not told & na & na & $0.71^{* *}$ & $0.74^{*}$ \\
\hline Religion & & & & & Was not at facility & na & na & $0.79^{*}$ & 0.85 \\
\hline Catholic (ref) & 1.00 & 1.00 & 1.00 & 1.00 & & & & & \\
\hline Protestant & 0.92 & 0.89 & 0.91 & 0.94 & \multicolumn{5}{|c|}{ No. of known family planning methods } \\
\hline Other & 0.96 & 0.90 & 0.90 & 0.91 & (mean,6.3) & na & na & $1.06^{* *}$ & $1.05^{* *}$ \\
\hline \multicolumn{5}{|l|}{ Locality } & \multicolumn{5}{|c|}{ Heard about family planning via media } \\
\hline Urban (ref) & 1.00 & 1.00 & 1.00 & 1.00 & Yes (ref) & na & na & 1.00 & 1.00 \\
\hline Rural & $0.67^{* *}$ & $0.79 \dagger$ & $0.80+$ & $0.79 \dagger$ & No & na & na & 0.99 & 1.07 \\
\hline \multicolumn{5}{|l|}{ Province } & \multicolumn{5}{|c|}{ Approves of family planning } \\
\hline Kigali (ref) & 1.00 & 1.00 & 1.00 & 1.00 & Yes (ref) & na & na & na & 1.00 \\
\hline East & 0.90 & 1.04 & 1.07 & 1.06 & No & na & na & na & $0.66^{* *}$ \\
\hline North & $0.64^{* *}$ & $0.70^{*}$ & $0.68^{*}$ & $0.67^{*}$ & No response & na & na & na & 0.98 \\
\hline West & $0.53^{* *}$ & $0.61^{* *}$ & $0.62^{* *}$ & $0.62^{* *}$ & & & & & \\
\hline \multirow[t]{2}{*}{ South } & $0.43^{* *}$ & $0.49^{* *}$ & $0.50^{* *}$ & $0.50^{* *}$ & \multicolumn{5}{|c|}{ Partner approves of family planning‡ } \\
\hline & & & & & Yes (ref) & na & na & na & 1.00 \\
\hline \multicolumn{5}{|c|}{ Household wealth index } & No & na & na & na & 0.99 \\
\hline Poorest (ref) & na & 1.00 & 1.00 & 1.00 & Don't know & na & na & na & $0.77 \dagger$ \\
\hline Poorer & na & 1.00 & 0.98 & 0.98 & & & & & \\
\hline Middle & na & 1.03 & 1.02 & 1.03 & \multicolumn{5}{|c|}{ Discussed family planning with partner } \\
\hline Richer & na & 0.96 & 0.93 & 0.94 & $\geq 3$ times (ref) & na & na & na & 1.00 \\
\hline \multirow[t]{2}{*}{ Richest } & na & $1.38^{*}$ & $1.30 \dagger$ & $1.32 \dagger$ & Once or twice & na & na & na & $0.76^{* *}$ \\
\hline & & & & & Never & na & na & na & $0.69^{* *}$ \\
\hline \multicolumn{5}{|l|}{ Partner's education $\neq$} & No response & na & na & na & $2.12^{* *}$ \\
\hline $0-2$ yrs. (ref) & na & 1.00 & 1.00 & 1.00 & & & & & \\
\hline $3-6 y r s$. & na & 1.05 & 1.04 & 1.05 & Constant & 0.04 & 0.03 & 0.02 & 0.02 \\
\hline 7-9yrs. & na & 1.17 & 1.14 & 1.16 & Pseudo $R^{2}$ & 0.340 & 0.349 & 0.356 & 0.367 \\
\hline$\geq 10$ yrs. & na & 1.18 & 1.13 & 1.17 & Prediction \% correct & 79.2 & 79.1 & 79.3 & 79.8 \\
\hline Don't know & na & 0.94 & 0.94 & 0.92 & & & & & \\
\hline \multicolumn{10}{|c|}{ Partner's occupation‡ } \\
\hline Agriculture (ref) & na & 1.00 & 1.00 & 1.00 & & & & & \\
\hline Craftsman & na & $1.59^{* *}$ & $1.54^{* *}$ & $1.51^{* *}$ & & & & & \\
\hline Mid-salaried & na & $1.64^{* *}$ & $1.59^{* *}$ & $1.56^{* *}$ & & & & & \\
\hline High-salaried & na & 1.11 & 1.07 & 1.07 & & & & & \\
\hline Don't know & na & $1.61 \dagger$ & $1.58+$ & $1.56 \dagger$ & & & & & \\
\hline
\end{tabular}

er models remained unchanged. Among the newly added variables, women's disapproval of family planning was negatively associated with desire for family limitation, as could be expected. This finding, however, may indicate that those who did not want to limit their family size were more liable to disapprove of contraception. Women who had little to no communication with their partner about family planning had lower odds of wanting to limit family size than those who had discussed the topic with their partner at least three times $(0.7-0.8)$.

\section{Unmet Need for Family Limitation}

As the first model in Table 4 shows, the odds of having an unmet need for means of family limitation were negatively and strongly associated with a woman's educational level.
Compared with women with 0-2 years of schooling, those with more education had significantly lower odds of having unmet need (odds ratios, 0.3-0.6). Protestant women had a significantly higher level of unmet need than Catholics (1.4). Surprisingly, there was no significant difference between rural and urban women in the odds of having an unmet need for permanent methods of contraception.

These findings remained similar with the addition of the household context variables (Model 2). Of the four new variables included in this model, only the partner's perceived desire for children was significant. Compared with women who believed that their partner's desire matched their own, those who believed that their partner desired more children than they themselves did and those who did not know their partner's desire were more likely 


\begin{tabular}{|c|c|c|c|c|c|c|c|c|c|}
\hline Variable & Model 1 & Model 2 & Model 3 & Model 4 & Variable & Model & Model 2 & Model 3 & Model 4 \\
\hline \multirow[t]{2}{*}{ Age (mean, 37.0 yrs.) } & $1.02 *$ & 1.01 & $1.02 \dagger$ & 1.01 & \multicolumn{5}{|c|}{ Partner's desired no. of children¥ } \\
\hline & & & & & Same (ref) & na & 1.00 & 1.00 & 1.00 \\
\hline Education & & & & & Fewer & na & 1.22 & 1.27 & 1.24 \\
\hline $0-2$ yrs. (ref) & 1.00 & 1.00 & 1.00 & 1.00 & More & na & $2.81^{* *}$ & $3.18^{* *}$ & $1.62^{*}$ \\
\hline $3-6$ yrs. & $0.63^{* *}$ & $0.68^{* *}$ & $0.71^{*}$ & $0.67^{*}$ & Don't know & na & $2.03^{* *}$ & $1.85^{* *}$ & 0.74 \\
\hline 7-9yrs. & $0.40^{* *}$ & $0.50^{* *}$ & $0.66^{*}$ & 0.69 & & & & & \\
\hline \multirow[t]{2}{*}{$\geq 10 \mathrm{yrs}$. } & $0.25^{* *}$ & $0.41^{* *}$ & 0.66 & 0.70 & \multicolumn{5}{|c|}{ Visited by family planning worker in previous 12 mos. } \\
\hline & & & & & Yes (ref) & na & na & 1.00 & 1.00 \\
\hline Occupation & & & & & No & na & na & 1.05 & 1.00 \\
\hline Agriculture (ref) & 1.00 & 1.00 & 1.00 & 1.00 & & & & & \\
\hline Not working & 1.22 & 1.27 & 1.08 & 0.91 & \multicolumn{5}{|c|}{ Told about family planning at health facility } \\
\hline \multirow{2}{*}{ Salaried } & $0.65+$ & 0.74 & 0.69 & 0.67 & Was told (ref) & na & na & 1.00 & 1.00 \\
\hline & & & & & Was not told & na & na & $1.87^{* *}$ & $1.63^{*}$ \\
\hline Religion & & & & & Was not at facility & na & na & $2.00^{*}$ & $1.59^{*}$ \\
\hline Catholic (ref) & 1.00 & 1.00 & 1.00 & 1.00 & & & & & \\
\hline Protestant & $1.44^{* *}$ & $1.46^{* *}$ & $1.46^{* *}$ & 1.22 & \multicolumn{5}{|c|}{ No. of known family planning methods } \\
\hline Other & 1.03 & 1.21 & 1.28 & 1.34 & (mean, 6.9) & na & na & $0.83^{* *}$ & $0.83^{* *}$ \\
\hline \multicolumn{5}{|l|}{ Locality } & \multicolumn{5}{|c|}{ Heard about family planning via media } \\
\hline Urban (ref) & 1.00 & 1.00 & 1.00 & 1.00 & Yes (ref) & na & na & 1.00 & 1.00 \\
\hline Rural & 1.22 & 1.08 & 1.07 & 1.17 & No & na & na & $1.39 *$ & 1.17 \\
\hline \multicolumn{5}{|l|}{ Province } & \multicolumn{5}{|c|}{ Approves of family planning } \\
\hline Kigali (ref) & 1.00 & 1.00 & 1.00 & 1.00 & Yes (ref) & na & na & na & 1.00 \\
\hline East & 1.00 & 0.91 & 0.84 & 0.73 & No & na & na & na & $2.89^{*}$ \\
\hline North & 1.32 & 1.24 & 1.32 & 1.40 & No response & na & na & na & 0.93 \\
\hline West & $1.59+$ & 1.33 & 1.14 & 1.10 & & & & & \\
\hline \multirow[t]{2}{*}{ South } & $1.63+$ & 1.45 & 1.38 & 1.27 & \multicolumn{5}{|c|}{ Partner approves of family planningł } \\
\hline & & & & & Yes (ref) & na & na & na & 1.00 \\
\hline \multicolumn{2}{|l|}{ Household wealth index } & & & & No & na & na & na & $4.11^{* *}$ \\
\hline Poorest (ref) & na & 1.00 & 1.00 & 1.00 & Don't know & na & na & na & $4.35^{* *}$ \\
\hline Poorer & na & 0.77 & 0.82 & 0.83 & & & & & \\
\hline Middle & na & 1.10 & 1.12 & 1.16 & \multicolumn{5}{|c|}{ Discussed family planning with partner } \\
\hline Richer & na & 1.02 & 1.13 & 1.22 & $\geq 3$ times (ref) & na & na & na & 1.00 \\
\hline \multirow{2}{*}{ Richest } & na & $0.68+$ & 0.82 & 0.91 & Once or twice & na & na & na & $1.88^{* *}$ \\
\hline & & & & & Never & na & na & na & $3.00^{* *}$ \\
\hline Partner's education‡ & & & & & No response & na & na & na & 1.10 \\
\hline $0-2$ yrs.(ref) & na & 1.00 & 1.00 & 1.00 & & & & & \\
\hline $3-6 y r s$. & na & 1.01 & 1.06 & 1.07 & Constant & 0.81 & 0.83 & 1.10 & 0.96 \\
\hline 7-9yrs. & na & 0.89 & 1.01 & 1.05 & Pseudo $R^{2}$ & 0.132 & 0.187 & 0.266 & 0.384 \\
\hline$\geq 10 \mathrm{yrs}$ & na & 0.81 & 0.93 & 0.86 & Prediction \% correct & 65.4 & 67.1 & 69.3 & 74.7 \\
\hline Don't know & na & 1.94 & 1.89 & 1.77 & & & & & \\
\hline \multicolumn{10}{|l|}{ Partner's occupation‡ } \\
\hline Agriculture (ref) & na & 1.00 & 1.00 & 1.00 & & & & & \\
\hline Craftsman & na & 0.76 & 0.92 & 0.90 & & & & & \\
\hline Mid-salaried & na & 0.76 & 0.83 & 0.83 & & & & & \\
\hline High-salaried & na & $0.59+$ & $0.56+$ & $0.52 \dagger$ & & & & & \\
\hline Don't know & na & 0.90 & 0.97 & 0.85 & & & & & \\
\hline
\end{tabular}

to have an unmet need for means of family limitation (2.8 and 2.0 , respectively).

When variables measuring exposure to contraceptive information and access to family planning services were added (Model 3), the odds of having unmet need were higher among uninformed women. Compared with women who had been told about contraception at a clinic, those who had not been told and those who had not visited a clinic were significantly more likely to have an unmet need for permanent methods (1.9 and 2.0, respectively). In addition, the odds of unmet need declined with each additional method known (0.8). Finally, women who had not heard of family planning methods through the media were significantly more likely than those who had to have an unmet need (1.4).
In the final model, all three measures of attitudes toward family planning were associated with unmet need. Other things being equal, the odds of having an unmet need were higher among women who disapproved of family planning (odds ratio, 2.9), those whose partners disapproved of family planning (4.1) and those who discussed family planning issues with their partners rarely or not at all (odds ratios, 1.9-3.0).

When the attitudinal variables were added, however, the significance of some of the variables included in earlier models changed (i.e., education, religion, partner's desire for children, and having obtained knowledge about family planning through media campaigns), suggesting that attitudinal variables drive these factors. In particular, the effect on women who indicated that they did not know 
their partners' desired number of children is striking: the odds changed from significantly positive (1.9) to negative but not significant (0.7), which suggests that discussion of family planning and knowing the partner's opinion about it may contribute to a lower risk of unmet need, even if the woman is not sure about her partner's desired number of offspring. The pseudo $\mathrm{R}^{2}$ values show that all models contributed to the explanation of unmet need; however, the contribution of Model 4 was more substantial than that of Models 2 and 3.

\section{DISCUSSION}

Rwanda can be characterized as a country in which modernization processes have not yet resulted in a substantial differentiation among women regarding the desire for family limitation. Preventing pregnancy becomes an option for women only as they advance in years or when their actual number of children approaches the desired number, regardless of their level of education, the type of work they perform or their religious background. A pronatalist attitude prevails, which makes family planning a low-priority issue at present.

However, some of our findings indicate a change in this attitude. For example, the proportion of women who want to limit their family size is higher in urban areas than in rural areas, and the proportion of women who desire to limit their family size is highest among women in the wealthiest households.

In most countries, the education of women is an important trigger for fertility decline. In Rwanda, however, a woman's level of education is not strongly associated with her desire to end childbearing. In our results, women with 10 or more years of education had lower odds of desiring to limit their families than women with less education.

More important than stimulating the desire to limit the number of children is tackling the unmet need for means of family limitation. The vast majority of women approve of family planning, but more than $50 \%$ of those who want to stop having children have an unmet need for modern contraception. Education and wealth seem to play roles in reducing unmet need, but the effects are limited. Talking about family planning is a taboo in many Rwandan households; the majority of women have never discussed family planning with their husband or have done so only once or twice, and many are not sure whether their partner approves of it. This turns out to be the major obstacle in the use of modern contraceptives. Health centers rarely inform their female clients about the opportunities for reproductive health care that are available, and some do not offer the services. Negative attitudes toward family planning and failing structures of provision are the dominant constraints on the use of modern contraceptives.

The present policy aimed at empowering women in Rwandan society is therefore important in the attempt to

*Ainsworth and colleagues show that the first three years of primary schooling are not related to fertility; thus, the relation between fertility and education is nonlinear (source: reference 21). reduce excess fertility. There is, however, a long way to go. In the age group 15-49 years, $40 \%$ of all women had received fewer than three years of education. Primary school attendance among females is increasing in Rwanda (net enrollment in primary school has risen to $86 \%$ ), but the quality of education is poor and many girls drop out early; enrollment in secondary school is extremely low (about $10 \%) .{ }^{15}$ Both observations indicate a real obstacle to making progress in the field of fertility control. ${ }^{21}$ *

The political climate in Rwanda now seems ripe for a more visible and persistent population policy that is geared to improving reproductive health and facilitating couples' desire to space or limit births. Our research suggests a variety of leverage points for both public- and private-sector social and programmatic interventions to reduce Rwandan fertility to levels found elsewhere in the developing world, including more successful African settings.

Our first recommendation is that interventions aimed at increasing contraceptive use should be targeted toward women with low levels of education. In the long run, the increasing education and empowerment of women will lead to a higher level of demand for and practice of family planning. Until then, providing all women with full access to family planning services will be instrumental in improving their position.

Our second recommendation is that interventions target the negative attitudes toward family planning that are an important cause of unmet need. Women's disapproval of family planning was strongly associated with unmet need, as were partners' desire to have more children and their disapproval of family planning. In present-day Rwanda, male attitudes are a major constraint on women's wish to limit the size of their families.

Providing examples influences the behavior of others in the household and the community, even among uneducated women living in unfavorable economic conditions. ${ }^{31}$ It is important to uncover the reasons for negative community attitudes toward family planning in order to involve these communities in discussions and programs on reproductive health

Our third recommendation concerns the impact of family planning efforts and the way in which women and men can be best informed. Research in Malawi ${ }^{32}$ revealed gender differentials in orientation on family planning issues, which stresses the importance of a separate approach. As our findings show, the dissemination of information about family planning through personal contact at health centers contributes to a higher level of desire for family limitation and a substantially lower level of unmet need.

Our final recommendation concerns access to family planning services. Although overall health expenditure has risen sharply, investments in reproductive health have remained relatively stable. Family planning services should become standard in all health centers in Rwanda. In addition, community-based family planning services could greatly expand access, especially in underserved provinces. Such services have been introduced in many parts of Africa 
and Asia, and have played a major role in increasing the access to and the supply of contraceptives. ${ }^{33,34}$

\section{REFERENCES}

1. United Nations Development Program (UNDP) Rwanda, Turning Vision 2020 into Reality: From Recovery to Sustainable Human Development, Kigali, Rwanda: UNDP Rwanda, 2007.

2. Verwimp PH, Development and genocide in Rwanda: a political economy analysis of peasants and power under the Habyarimana regime, unpublished dissertation, Leuven, Belgium: Economics Department, Catholic University of Leuven, 2003.

3. Hakizimana E, Some considerations on family planning and contraception worldwide and in Rwanda, Famille, Sante, Developpement/ Imbonezamuryango, 1988, No. 12, pp. 21-26

4. Rwanda National Institute of Statistics, Rwanda Demographic and Health Survey 2005, Calverton, MD, USA: ORC Macro, 2006

5. Advance Africa, Summary of Findings and Recommendations of Family Planning Qualitative Assessment in Rwanda, Kigali, Rwanda: Advance Africa, 2002

6. May JF, Mukamanzi M and Vekemans M, Family planning in Rwanda: status and prospects, Studies in Family Planning, 1990, 21(1):20-32.

7. May JF, Policies on population land use and environment in Rwanda, Population and Environment, 1995, 16(4):321-334.

8. Westoff CF and Bankole A, Trends in the demand for family limitation in developing countries, International Family Planning Perspectives, 2000, 26(2):56-62

9. Rwanda National Institute of Statistics, Rwanda Demographic and Health Survey 1992, Calverton, MD, USA: Macro International, 1994

10. Sexuality Information and Education Council of the United States (SIECUS), Rwandan government proposes legislation limiting family size, $<$ http://www.siecus.org/index.cfm?fuseaction=Feature.showFeature $\&$ featureid=973\&pageid=642\&parentid=633>, accessed July 18, 2007.

11. Remarks by His Excellency Paul Kagama at the African Climate Change Forum, London, Nov. 11, 2008.

12. Rwanda Ministry of Finance and Economic Planning, Economic Development and Poverty Reduction Strategy 2008-2012, Kigali, Rwanda: Ministry of Finance and Economic Planning, 2007.

13. Population Division, United Nations (UN), World Contraceptive Use 2005, New York: UN, 2005

14. Bongaarts J, The causes of stalling fertility transitions, Policy Research Division Working Papers, New York: Population Council, 2005, No. 204.

15. Rwanda National Census Service, Synthesis of Results, Kigali, Rwanda: National Census Service, 2003.

16. Rwanda National Institute of Statistics, Service Provision Assessment Survey, Kigali, Rwanda: National Institute of Statistics, 2008

17. Solo J, Family planning in Rwanda: how a taboo topic became priority number one, IntraHealth, 2008, <http://www.intrahealth.org/assets/ uploaded/countries/FP_in_Rwanda.pdf>, accessed Dec. 3, 2008.

18. Westoff CF, New estimates of unmet need and the demand for family planning, DHS Comparative Reports, Calverton, MD, USA: ORC Macro, 2006, No. 14

19. Kravdal O, Education and fertility in Sub-Saharan Africa: individual and community effects, Demography, 2002, 39(2):233-250.

20. Agyei WK and Migadde M, Demographic and socio-cultural factors influencing contraceptive use in Uganda, Biosocial Science, 1995, 27(1): $47-60$.

21. Ainsworth M, Beegle K and Nyamete A, The impact of women's schooling on fertility and contraceptive use: a study of fourteen SubSaharan African countries, Washington, DC: International Bank for Reconstruction and Development/World Bank, 1996.

22. Agadjanian V, Religion, social milieu and the contraceptive revolution, Population Studies, 2001, 55(2):135-148.

23. Dodoo FN and Tempenis M, Gender, power and reproduction: ruralurban differences in the relationship between fertility goals and contra- ceptive use in Kenya, Rural Sociology, 2002, 67(1):46-71.

24. Cohen B, Family planning programs, socio-economic characteristics and use in Malawi, World Development, 2000, 28(5):843-860.

25. Talnan E and Vimard P, Développement local, pauvreté et practique contraceptive en Cote d'Ivoire, paper presented at the fourth African Population Conference, Tunis, Tunisia, Dec. 8-12, 2003.

26. Becker S, Measuring unmet need: wives, husbands or couples? International Family Planning Perspectives, 1999, 25(4):172-180

27. Westoff CF and Rodriguez G, The mass media and family planning in Kenya, International Family Planning Perspectives, 1995, 21(1):26-31 \& 36.

28. DeRose LF et al., Does discussion of family planning improve knowledge of partner's attitude toward contraceptives? International Family Planning Perspectives, 2004, 30(2):87-93.

29. Wolff B, Blanc AK and Ssekamatte-Ssebuliba J, The role of couple negotiation in unmet need for contraception and decision to stop childbearing in Uganda, Studies in Family Planning, 2000, 31(2):124-137.

30. Brockerhoff M and Yang X, Impact of migration on fertility in SubSaharan Africa, Social Biology, 1994, 41(1-2):19-43.

31. McNay K, Arokiasamy P and Cassen RH, Why are uneducated women in India using contraception? a multilevel analysis, Population Studies, 2003, 57(1):21-40

32. Paz Soldan VA, How family planning ideas are spread within social groups in rural Malawi, Studies in Family Planning, 2004, 35(4):275-290

33. Korra A, Attitudes toward family planning and reasons for nonuse among women with unmet need for family planning in Ethiopia, Calverton, MD, USA: ORC Macro, 2002

34. Shelton JD, Putting unmet need to the test: community-based distribution of family planning in Pakistan, International Family Planning Perspectives, 1999, 25(4):191-195.

\section{RESUMEN}

Contexto: Ruanda es el país más densamente poblado de África, con un sustancial crecimiento anual de la población. El actual gobierno busca establecer nuevas politicas para limitar el tamaño de las familias como medio para facilitar un desarrollo más sostenible.

Métodos: Datos de la Encuesta Demografia y Salud de Ruanda de 2005 fueron usados para un análisis de dos pasos; se usó regresión logística binaria para identificar factores asociados con el deseo de no tener más hijos y de tener necesidad insatisfecha de anticoncepción.

Resultados: Ochenta y siete por ciento de las mujeres en edades de 15-49 aprueban el uso de la planificación familiar, pero solamente $64 \%$ consideran que sus parejas la aprueban. Hay un alto nivel de necesidad insatisfecha para limitar la familia; 58\% de las mujeres que desean dejar de tener hijos no usan anticonceptivos modernos. La demanda fue más baja en mujeres que no aprobaban la planificación familiar, en las que no conocian la actitud de su pareja respecto a la planificación familiar y en quienes trataron el tema de la planificación familiar con su pareja menos de tres veces. La necesidad insatisfecha fue más alta en mujeres que no aprobaban la planificación familiar, en las que créán que su pareja no la aprobaba o que desconocian su actitud, y en aquellas que nunca habían tratado el tema de la planificación familiar con su pareja o lo habian hecho sólo una o dos veces.

Conclusiones: Las limitaciones dominantes para el uso de anticonceptivos modernos en Ruanda son las actitudes negativas hacia la planificación familiar y las defectuosas estructu- 
ras de prestación de servicios. Los servicios de planificación familiar basados en la comunidad podrían expandir el acceso significativamente, especialmente en las provincias insuficientemente atendidas.

\section{RÉSUMÉ}

Contexte: Le Rwanda est le pays d'Afrique qui présente la plus forte densité de population et sa croissance démographique annuelle est considérable. Le gouvernement actuel cherche à définir de nouvelles politiques de limitation des familles au profit d'un développement plus durable.

Méthodes: Les données de l'Enquête démographique et de santé (EDS) 2005 du Rwanda ont servi à la réalisation d'une analyse en deux étapes. Les facteurs associés au désir de ne plus avoir d'enfants et au besoin non satisfait ont été identifiés par régression logistique binaire.

Résultats: Quatre-vingt-sept pour cent des femmes de 15 à 49 ans approuvent la planification familiale; 64\% seulement croient cependant que leur partenaire y est favorable. Le niveau du besoin non satisfait de limitation des naissances est élevé: 58\% des femmes qui ne désirent plus avoir d'enfants ne pratiquent pas la contraception moderne. La demande est moindre parmi les femmes qui n'approuvent pas la planification familiale, qui ignorent la position de leur partenaire à son égard ou qui ont abordé la question avec leur partenaire moins de trois fois. Le besoin non satisfait est supérieur parmi les femmes qui n'approuvent pas la planification familiale, celles qui pensent que leur partenaire ne l'approuve pas ou qui ignorent sa position sur la question et celles qui n'ont jamais abordé la question avec leur partenaire ou qui ne l'ont abordée qu'une ou deux fois. Conclusions: Les attitudes négatives à l'égard de la planification familiale et les faibles structures de prestations sont les principaux obstacles à la pratique de la contraception moderne au Rwanda. Les services de planification familiale à l'échelle de la collectivité pourraient améliorer grandement l'accès, en particulier dans les provinces sous-desservies.

\section{Acknowledgments}

The research on which this article is based was supported by grant W07-40-202-00 from The Netherlands Organisation for Scientific Research/The William and Flora Hewlett Foundation research program and grant NPT-RWA-053 from The Netherlands Organisation for International Cooperation in Higher Education.

Authorcontact: dieumu_res@yahoo.fr 